\title{
Effect of commercial carbohydrases on the hesperetin and narigenin contents of citrus fruits
}

\author{
Kwang-Seup Shin, Hyeon-Jun Chang, Jeung-Hee Lee* \\ Department of Food and Nutrition, Daegu University, Gyeonsan 38453, Korea
}

\begin{abstract}
Citrus fruits were treated with commercial carbohydrases to produce hydrolyzed citrus with higher amounts of hesperetin and narigenin. The suitable enzymatic reaction conditions were determined using standard hesperidin and naringin with three carbohydrases (Viscozyme L $>$ AMG 300L > Pectinex Ultra Pulp), varying reaction buffer pH levels $(5.0>4.0>6.0)$ and reaction times $(24 \mathrm{~h}>2 \mathrm{~h})$. Viscozyme $\mathrm{L}$ produced significantly higher contents of hesperetin and narigenin than the other enzymes $(p<0.05)$, and the contents increased with reaction time. With Viscozyme $\mathrm{L}$, higher contents of hesperetin and narigenin (1.63 and 2.10 times) and higher total phenolic contents (1.69 times) were produced in the hydrolyzed immature citrus relative to those in the hydrolyzed mature citrus $(\mathbf{p}<0.05)$. In addition to the minimum inhibitory concentration of the hydrolyzed immature citrus was lower against Staphylococcus aureus than against Escherichia coli. Thus, enzymatic hydrolysis with immature citrus appears to produce much higher contents of hesperetin, narignenin and total phenolic contents than with the mature citrus, and enzymatic hydrolysis could improve the quality of citrus beverages. Hydrolyzed citrus would likely serve as a functional food additive with high added value in the citrus processing industry.
\end{abstract}

Key words : carbohydrase, citrus, hesperetin, narigenin, total phenolic content

\section{Introduction}

Jeju citrus, the most widely produced fruit in Korea, contains vitamin $\mathrm{C}$, organic acids, free sugars, and minerals as well as bioactive substances such as essential oils, flavonoids, carotenoids, coumarins, and limonoids (Lee et al., 2005; Song et al., 1998). Flavonoids include hesperidin, naringin, naringenin, hesperetin, and polymethoxylated flavones (PMFs; tangeretin and nobiletin) (Song et al., 2013). Flavonoids are present at higher levels in the peel than in the pulp, and have been associated with a reduced risk of coronary heart disease as well as anti-carconogenic, anti-oxidant, anti-inflammatory, anti-microbial and antiproliferative activities (Kawaii et al., 2012; Yao et al., 2012; Hyun et al., 2015).
Citrus flavonoids are present in the form of glycosides or aglycone, and the major flavonoids are non-active glycosides, such as naringin and hesperidin. The sugars that constitute glycosides are glucose, arabinose, galactose, rhamnose, and xylose, which are mostly linked to aglycone by $\alpha-1,4$ or $\beta$ 1,4 bonds (Tripoli et al., 2007). Hesperidin is hesperetin (aglycone) attached to rutinose (rhamnose and glucose), and naringin is narigenin (aglycone) attached to two rhamnose units. Although these flavonoids have antioxidant activity, hesperidin and naringin show lower antioxidant activity than hesperetin and naringenin because the sugar moiety causes a structurally steric hindrance of the scavenging group (Tripoli et al., 2007).

Hesperidin and naringin have limited bioavailabilities due to the attached sugar moiety which is the major determinant

*Corresponding author. E-mail : jeunghlee@daegu.ac.kr, Phone : +82-53-850-6836, Fax : +82-53-850-6839

Received 04 October 2019; Revised 15 December 2019; Accepted 18 December 2019.

Copyright (c) The Korean Society of Food Preservation.

This is an Open Access article distributed under the terms of the Creative Commons Attribution Non-Commercial License (http://creativecommons.org/licenses/by-nc/4.0) which permits unrestricted non-commercial use, distribution, and reproduction in any medium, provided the original work is properly cited. 
of an absorption of dietary flavonoids. Flavonoid glycosides with rhamnose are poorly absorbed compared to their glucosides or aglycones (Hollman et al., 1999). Several studies focusing on the bioavailability of flavonoids with rutin, hesperidin or isoflavone have been reported in rats and human (Arts et al., 2004). The absorption of rutin (quercetin with rhamnose) is slower than quercetin with glucose and the quercetin itself (Hollman et al., 1999), and soy isoflavone aglycones are absorbed faster than their glucosides in humans (Izumi et al., 2000). Hesperetin glucoside is more bioavailable than hesperidin in humans, and the associated study results demonstrated that the enzymatic modification of hesperidin by the removal of rhamnose improved the bioavailability of hesperetin (Nielsen et al., 2006).

Since most citrus flavonoids are present inside cells, they must be released to the outside of the cells to have bioactive effects after being ingested. When cell-wall polysaccharides (pectin, cellulose, hemicellulose, and $\beta$-1,4-glucan) are decomposed, flavonoid compounds are released to the outside and can be converted into their aglycone by an enzyme secreted by microorganisms present in the intestinal tract. For example, ingested hesperidin reaches the small intestine, and is converted into hesperetin by the bacteria producing $\alpha$-rhamnosidase and $\beta$-glucosidase or endo- $\beta$ -glucosidase (Garg et al., 2001). This deglycosylation process by $\beta$-glucosidase is known to play an important role in the absorption and metabolism of flavonoid glycosides (Ahn et al., 2005).

The presence of insoluble components in citrus fruits accounts for the characteristics of taste, aroma, and juice color as well as causes a turbidity in the juice. Maceration enzymes (a mixture of pectinase, hemicellulase, and cellulase) are used to clarify and decrease the viscosity of citrus juice, by acting on the hydrolysis of pectin and cell wall components (Ribeiro et al., 2010). Naringinase is also used for removing naringin, a key substance that contributes to the bitterness of citrus fruit. Commercial enzymes in single or mixed forms of carbohydrases are often used to improve the manufacturing process and quality of citrus beverages and can convert citrus flavonoid glycosides into aglycones, resulting in enhanced functional effects (Ahn et al., 2005).

In this study, citrus fruits were treated with commercial enzymes to produce a hydrolyzed citrus containing increased bioactive compounds. Standard hesperidin and naringin were hydrolyzed by three commercial carbohydrases under different reaction conditions (enzyme type, reaction buffer $\mathrm{pH}$ level, and reaction time) to determine the suitable reaction conditions for producing higher amounts of hesperetin and narigenin. Under the selected reaction conditions, mature and immature citrus fruits were hydrolyzed with the enzymes, and hesperetin and narigenin contents as well as antioxidant and antimicrobial activities were compared.

\section{Materials and methods}

\section{Materials}

Immature citrus cultivated in Jeju-do was provided by Fresh Bell Co., Ltd. (Gyeongsan, Korea). Mature citrus was purchased from a nearby supermarket. The citrus fruits were crushed into both peel and pulp using a blender. Standard hesperidin and hesperetin, gallic acid and Folin-Ciocalteu reagent were purchased from Sigma Chemical Co., Ltd. (St. Louis, MO, USA). Acetic acid from Samchun Pure Chemical Co., Ltd. (Seoul, Korea), and methanol and water with HPLC grade from J. T. Baker (Center Valley, PA, USA) were purchased. The enzymes (Viscozyme L, AMG 300L, and Pectinex Ultra Pulp) were obtained from Novozymes (Bagsværd, Denmark).

\section{Enzymatic hydrolysis of hesperidin and naringin}

Standard hesperidin or naringin ( $2 \mathrm{mg})$, sodium acetate buffer (pH 4.0, 5.0, or 6.0; $2 \mathrm{~mL}$ ), and enzyme (Viscozyme L, AMG 300L, or Pectinex Ultra Pulp, $100 \mu \mathrm{L}$ ) were mixed in a $50 \mathrm{~mL}$ vial, and incubated in a shaking water bath $(5$ $0^{\circ} \mathrm{C}$ and $\left.150 \mathrm{rpm}\right)$ for 2 and $24 \mathrm{~h}$. Next, the reaction mixture was boiled in a $90-100^{\circ} \mathrm{C}$ water bath for $20 \mathrm{~min}$ to deactivate the enzyme and lyophilized for 3 days (PVTFD20R, Ilshin Bio Base, Dongducheon, Korea). The lyophilized sample was extracted with methanol $(40 \mathrm{~mL})$ by sonication for $2 \mathrm{~h}$, and centrifuged at $1,763 \times \mathrm{g}$ for $10 \mathrm{~min}$. The obtained supernatant was filtered through a syringe filter and used in this study.

\section{Enzymatic hydrolysis of immature and mature citrus}

The crushed citrus was diluted to $2 \mathrm{x}$ with sodium acetate buffer, and titrated to $\mathrm{pH} 5.0$. The enzyme $(2 \%(\mathrm{w} / \mathrm{w})$ of the 
citrus) was added, and incubated in a shaking water bath $\left(50^{\circ} \mathrm{C}\right.$ and $\left.150 \mathrm{rpm}\right)$ for 2 and $24 \mathrm{~h}$. After the reaction, the hydrolyzed citrus was boiled, lyophilized, and extracted with methanol $(40 \mathrm{~mL})$ by sonication for $2 \mathrm{~h}$. After centrifugation the supernatant was obtained.

\section{Quantification of flavonoids with HPLC}

An HPLC (LC-20AD, Shimazu Corp., Kyoto, Japan)

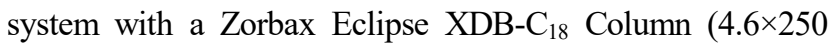
$\mathrm{mm}, 5 \mu \mathrm{m}$; Agilent Technologies, Santa Clara, CA, USA) and a UV detector was used for quantitative analysis of hesperidin, hesperetin, naringin, and narigenin. Solvent A (methanol) and solvent B ( $0.5 \%$ acetic acid) were used as mobile phase solvents and the flow rate was set to 1.0 $\mathrm{mL} / \mathrm{min}$. Gradient elution was carried out with the following gradients: maintain the ratio of solvent $\mathrm{A}$ and solvent $\mathrm{B}$ at 15:85 (v/v) for $3 \mathrm{~min}$, increase the ratio to $85: 15$ over 30 min and hold for $2 \mathrm{~min}$, then decrease back to $15: 85$ over $3 \mathrm{~min}$ and hold for $5 \mathrm{~min}$. The injection volume was set to $10 \mu \mathrm{L}$, column temperature to $31^{\circ} \mathrm{C}$, and $\mathrm{UV}$ detection to $280 \mathrm{~nm}$. A standard solution was prepared up to $500 \mathrm{ppm}$, and the standard curve was obtained through HPLC analysis under the same conditions, and the contents of hesperedin, hesperetin, naringin, and narigenin were quantified.

\section{Total phenolic contents (TPCs) of the hydrolyzed immature and mature citrus}

Methanol extract of the hydrolyzed mature or immature citrus $(0.5 \mathrm{~mL}), 4.5 \mathrm{~mL}$ of distilled water $(4.5 \mathrm{~mL})$, and Folin-Ciocalteu reagent $(0.5 \mathrm{~mL})$ were mixed in a test tube and left for $3 \mathrm{~min}$. Next, $1 \mathrm{~mL}$ of $1 \mathrm{~N} \mathrm{Na}_{2} \mathrm{CO}_{3}$ was added and placed in a dark room for $1 \mathrm{~h}$, and the absorbance was measured at $725 \mathrm{~nm}$ with a UV/VIS spectrophotometer (Optizen 2120UV; Mecasys Co., Ltd., Daejeon, Korea). The calibration curve was prepared using gallic acid (1, 0.8, 0.6, 0.4 , and $0.2 \mathrm{mM}$ ) and the TPCs were calculated, and expressed as mg gallic acid equivalent (GAE)/g citrus.

\section{DPPH radical scavenging capacities (RSC) of the hydrolyzed immature and mature citrus}

Five-fold diluted methanol extract $(0.2 \mathrm{~mL})$, methanol $(1.8$ $\mathrm{mL}$ ), and $0.15 \mathrm{mM}$ 2,2-diphenyl-1-picrylhydrazyl (DPPH) reagent $(2.5 \mathrm{~mL})$ were mixed in a test tube and placed in a dark place for $30 \mathrm{~min}$. The absorbance was measured at
$517 \mathrm{~nm}$, and the DPPH RSC was obtained using the following formula:

$$
\begin{aligned}
& \text { DPPH RSC }(\%)=\left[\left(A_{B}-A_{S}\right) / A_{B}\right] \times 100 \\
& A_{B}=\text { absorbance of blank (ethanol) } \\
& A_{S}=\text { absorbance of sample }
\end{aligned}
$$

\section{Antimicrobial activity of the hydrolyzed immature citrus}

Staphylococcus aureus (KCCM 12256) was purchased from the Korean Culture Center of Microorganisms (KCCM, Seoul, Korea), and Escherichia coli (KCTC 2593) was obtained from the Korean Collection for Type Cultures (KCTC, Jeongeup, Korea). The strains were cultured in a tryptic soy broth (TSB) medium at $37^{\circ} \mathrm{C}$ for $24 \mathrm{~h}$. A concentration of $300 \mathrm{mg} / \mathrm{mL}$ of immature citrus hydrolysate (0, 2 and $24 \mathrm{~h})$ was prepared with TSB medium, and serial 2-fold dilutions were prepared up to $0.07 \mathrm{mg} / \mathrm{mL}$. Next, 1 $\mathrm{mL}$ of the hydrolysate-mixed TSB medium at various concentrations was placed into each well of a 96-well deep plate (Simport ${ }^{\mathbb{R}}$; Beloeil, QC, Canada), and $10 \mu \mathrm{L}$ of the diluted strain culture medium was inoculated into the mixed medium and cultured in a shaking incubator for $24 \mathrm{~h}$ at 3 $7^{\circ} \mathrm{C}$ and $150 \mathrm{rpm}$. After incubation, the concentration of the mixed medium with no strain growth in the well plate was determined as the minimum inhibitory concentration (MIC).

\section{Statistical analysis}

The analysis of variance was performed with the Statistical Analysis System 9.2 (SAS Institute Inc., Cary, NC, USA), and the statistical difference of the means was determined by the Student's t-test or Duncan's multiple range test at a significance level of $\mathrm{p}<0.05$.

\section{Results and discussions}

\section{Hesperetin and narigenin contents in enzymatically hydrolyzed hesperidin and naringin}

Conversion of the standards (10 ppm) of hesperidin and naringin into hesperetin and narigenin, respectively, was performed with different types of enzymes (Viscozyme L, AMG 300L and Pectinex Ultra Plup), reaction buffer $\mathrm{pH}$ levels (4.0, 5.0, and 6.0), and reaction times (2 and $24 \mathrm{~h}$ ), and the reduction of hesperidin and naringin as well as the 
production of hespereitin and narigenin were compared based on the reaction conditions (Table 1). Hesperetin production was higher in the order of enzyme Viscozyme L $>$ Pectinex Ultra Pulp $>$ AMG 300L $(\mathrm{p}<0.05)$ (except for $24 \mathrm{~h}$ at $\mathrm{pH} 6.0$ ), reaction time of $24 \mathrm{~h}>2 \mathrm{~h}$, and $\mathrm{pH}$ level of $5.0>\mathrm{pH} 4.0$ and 6.0. At $\mathrm{pH} 5.0$, the production rate of hesperetin by Viscozyme L was 4.6 times and 1.9 times higher (at $2 \mathrm{~h}$ ), as well as 2.8 times and 1.1 times higher (at $24 \mathrm{~h}$ ) than those of AMG 300L and Pectinex Ultra Pulp, respectively. The combination of enzymatic reaction conditions for the highest production of hesperetin were Viscozyme L, $\mathrm{pH} 5.0$, and $24 \mathrm{~h}$.

Narigenin production was significantly higher in the order of Viscozyme L > AMG 300L > Pectinex Ultra Pulp at a $2 \mathrm{~h}$ reaction time $(\mathrm{p}<0.05)$, and for the $24 \mathrm{~h}$-reaction time, Viscozyme L at $\mathrm{pH} 4.0$ and $\mathrm{AMG} 300 \mathrm{~L}$ at $\mathrm{pH} 5.0$ and 6.0 produced significantly higher contents of narigenin $(\mathrm{p}<0.05)$ (Table 2). Unusually, when Viscozyme L was used, the content of the standard naringin (10 ppm) was remarkably reduced to $0.06-0.36 \mathrm{ppm}$ while the content of narigenin considerably increased to 2.79-3.44 ppm during the $2 \mathrm{~h}$ reaction. Over the $24 \mathrm{~h}$ reaction time, the narigenin content tended to decrease ( $\mathrm{pH} 5.0$ ) or maintain $(\mathrm{pH} 4.0$ and 6.0). On the other hand, the contents of naringin and narigenin by AMG 300L and Pectinex Ultra Pulp in the $2 \mathrm{~h}$ reaction time were 4.18-8.68 ppm and 0.5-1.60 ppm, respectively. As for the $24 \mathrm{~h}$ reaction time, the content of naringin remarkably decreased, and the content of narigenin increased to 2.30-3.66 ppm. With the utilization of enzymatic hydrolysis in this study, the conversion from naringin to narigenin was the highest by Viscozyme L (except for $\mathrm{pH}$ 5.0 at $24 \mathrm{~h}$ ). The optimal conditions for narigenin and

Table 1. The contents of hesperidin and hesperetin of the hydrolyzed hesperidin by three commercial enzymes

(unit: ppm)

\begin{tabular}{|c|c|c|c|c|c|c|c|c|c|c|c|c|}
\hline \multirow{4}{*}{ Enzyme } & \multicolumn{12}{|c|}{ Hydrolyzed hesperidin } \\
\hline & \multicolumn{4}{|c|}{$\mathrm{pH} 4.0$} & \multicolumn{4}{|c|}{ pH 5.0} & \multicolumn{4}{|c|}{$\mathrm{pH} 6.0$} \\
\hline & \multicolumn{2}{|c|}{$2 \mathrm{~h}$} & \multicolumn{2}{|c|}{$24 \mathrm{~h}$} & \multicolumn{2}{|c|}{$2 \mathrm{~h}$} & \multicolumn{2}{|c|}{$24 \mathrm{~h}$} & \multicolumn{2}{|c|}{$2 \mathrm{~h}$} & \multicolumn{2}{|c|}{$24 \mathrm{~h}$} \\
\hline & $\begin{array}{c}\text { Hes- } \\
\text { peridin }\end{array}$ & $\begin{array}{l}\text { Hes- } \\
\text { peretin }\end{array}$ & $\begin{array}{l}\text { Hes- } \\
\text { peridin }\end{array}$ & $\begin{array}{l}\text { Hes- } \\
\text { peretin }\end{array}$ & $\begin{array}{l}\text { Hes- } \\
\text { peridin }\end{array}$ & $\begin{array}{l}\text { Hes- } \\
\text { peretin }\end{array}$ & $\begin{array}{l}\text { Hes- } \\
\text { peridin }\end{array}$ & $\begin{array}{l}\text { Hes- } \\
\text { peretin }\end{array}$ & $\begin{array}{l}\text { Hes- } \\
\text { peridin }\end{array}$ & $\begin{array}{l}\text { Hes- } \\
\text { peretin }\end{array}$ & $\begin{array}{l}\text { Hes- } \\
\text { peridin }\end{array}$ & $\begin{array}{l}\text { Hes- } \\
\text { peretin }\end{array}$ \\
\hline Viscozyme L & $\begin{array}{c}5.82 \\
\pm 0.01^{\mathrm{c} 1)}\end{array}$ & $\begin{array}{c}2.78 \\
\pm 0.00^{\mathrm{a}}\end{array}$ & $\begin{array}{c}4.26 \\
\pm 0.02^{\mathrm{c}}\end{array}$ & $\begin{array}{c}3.55 \\
\pm 0.02^{\mathrm{a}}\end{array}$ & $\begin{array}{c}6.06 \\
\pm 0.03^{\mathrm{c}}\end{array}$ & $\begin{array}{c}2.63 \\
\pm 0.02^{\mathrm{a}}\end{array}$ & $\begin{array}{c}3.20 \\
\pm 0.03^{\mathrm{c}}\end{array}$ & $\begin{array}{c}3.83 \\
\pm 0.02^{\mathrm{a}}\end{array}$ & $\begin{array}{c}5.67 \\
\pm 0.01^{\mathrm{c}}\end{array}$ & $\begin{array}{c}2.48 \\
\pm 0.00^{\mathrm{a}}\end{array}$ & $\begin{array}{c}4.07 \\
\pm 0.01^{\mathrm{b}}\end{array}$ & $\begin{array}{r}3.31 \\
\pm 0.03^{\mathrm{b}}\end{array}$ \\
\hline AMG 300L & $\begin{array}{l}11.27 \\
\pm 0.07^{\mathrm{a}}\end{array}$ & $\begin{array}{c}0.45 \\
\pm 0.00^{\mathrm{c}}\end{array}$ & $\begin{array}{c}9.10 \\
\pm 0.02^{\mathrm{a}}\end{array}$ & $\begin{array}{c}1.32 \\
\pm 0.00^{\mathrm{c}}\end{array}$ & $\begin{array}{c}8.92 \\
\pm 0.02^{\mathrm{b}}\end{array}$ & $\begin{array}{c}0.59 \\
\pm 0.00^{\mathrm{c}}\end{array}$ & $\begin{array}{r}8.51 \\
\pm 0.03^{\mathrm{a}}\end{array}$ & $\begin{array}{c}1.35 \\
\pm 0.00^{\mathrm{c}}\end{array}$ & $\begin{array}{l}11.19 \\
\pm 0.03^{\mathrm{a}}\end{array}$ & $\begin{array}{c}0.38 \\
\pm 0.02^{\mathrm{c}}\end{array}$ & $\begin{array}{c}9.94 \\
\pm 0.02^{\mathrm{a}}\end{array}$ & $\begin{array}{c}0.91 \\
\pm 0.03^{\mathrm{c}}\end{array}$ \\
\hline $\begin{array}{l}\text { Pectinex } \\
\text { Ultra Pulp }\end{array}$ & $\begin{array}{c}9.60 \\
\pm 0.11^{b}\end{array}$ & $\begin{array}{c}1.22 \\
\pm 0.00^{\mathrm{b}}\end{array}$ & $\begin{array}{c}4.49 \\
\pm 0.02^{\mathrm{b}}\end{array}$ & $\begin{array}{c}3.18 \\
\pm 0.01^{\mathrm{b}}\end{array}$ & $\begin{array}{c}10.22 \\
\pm 0.07^{\mathrm{a}}\end{array}$ & $\begin{array}{c}1.41 \\
\pm 0.01^{\mathrm{b}}\end{array}$ & $\begin{array}{c}4.92 \\
\pm 0.00^{\mathrm{b}}\end{array}$ & $\begin{array}{r}3.64 \\
\pm 0.01^{\mathrm{b}}\end{array}$ & $\begin{array}{c}9.21 \\
\pm 0.00^{\mathrm{b}}\end{array}$ & $\begin{array}{c}1.08 \\
\pm 0.02^{\mathrm{b}}\end{array}$ & $\begin{array}{c}3.23 \\
\pm 0.00^{\mathrm{c}}\end{array}$ & $\begin{array}{c}3.67 \\
\pm 0.03^{\mathrm{a}}\end{array}$ \\
\hline
\end{tabular}

${ }^{1) a-c}$ Means within the same column with different superscript letters are significant different by Duncan's multiple range test at $\mathrm{p}<0.05$ ( $\mathrm{n}=3$ ).

Table 2. The contents of naringin and narigenin of the hydrolyzed naringin by three commercial enzymes

(unit: ppm)

\begin{tabular}{|c|c|c|c|c|c|c|c|c|c|c|c|c|}
\hline \multirow{4}{*}{ Enzyme } & \multicolumn{12}{|c|}{ Hydrolyzed naringin } \\
\hline & \multicolumn{4}{|c|}{$\mathrm{pH} 4.0$} & \multicolumn{4}{|c|}{$\mathrm{pH} 5.0$} & \multicolumn{4}{|c|}{$\mathrm{pH} 6.0$} \\
\hline & \multicolumn{2}{|c|}{$2 \mathrm{~h}$} & \multicolumn{2}{|c|}{$24 \mathrm{~h}$} & \multicolumn{2}{|c|}{$2 \mathrm{~h}$} & \multicolumn{2}{|c|}{$24 \mathrm{~h}$} & \multicolumn{2}{|c|}{$2 \mathrm{~h}$} & \multicolumn{2}{|c|}{$24 \mathrm{~h}$} \\
\hline & Naringin & Narigenin & Naringin & Narigenin & Naringin & Narigenin & Naringin & Narigenin & Naringin & Narigenin & Naringin & Narigenin \\
\hline $\begin{array}{c}\text { Viscozyme } \\
\text { L }\end{array}$ & $\begin{array}{c}0.06 \\
\pm 0.00^{\mathrm{cl})}\end{array}$ & $\begin{array}{c}2.93 \\
\pm 0.03^{\mathrm{a}}\end{array}$ & $\begin{array}{c}0.06 \\
\pm 0.00^{\mathrm{b}}\end{array}$ & $\begin{array}{c}2.95 \\
\pm 0.01^{\mathrm{a}}\end{array}$ & $\begin{array}{c}0.36 \\
\pm 0.01^{\mathrm{c}}\end{array}$ & $\begin{array}{c}3.44 \\
\pm 0.07^{\mathrm{a}}\end{array}$ & $\begin{array}{c}0.07 \\
\pm 0.00^{\mathrm{b}}\end{array}$ & $\begin{array}{c}2.95 \\
\pm 0.00^{\mathrm{c}}\end{array}$ & $\begin{array}{c}0.32 \\
\pm 0.00^{\mathrm{c}}\end{array}$ & $\begin{array}{c}2.79 \\
\pm 0.00^{\mathrm{a}}\end{array}$ & $\begin{array}{c}0.05 \\
\pm 0.00^{\mathrm{b}}\end{array}$ & $\begin{array}{c}2.90 \\
\pm 0.02^{\mathrm{b}}\end{array}$ \\
\hline AMG 300L & $\begin{array}{c}5.11 \\
\pm 0.09^{\mathrm{b}}\end{array}$ & $\begin{aligned} & 1.31 \\
\pm & 0.05^{\mathrm{b}}\end{aligned}$ & $\begin{array}{c}1.88 \\
\pm 0.01^{\mathrm{a}}\end{array}$ & $\begin{array}{c}2.30 \\
\pm 0.00^{\mathrm{c}}\end{array}$ & $\begin{array}{c}6.63 \\
\pm 0.01^{\mathrm{b}}\end{array}$ & $\begin{array}{c}1.28 \\
\pm 0.07^{\mathrm{b}}\end{array}$ & $\begin{array}{c}0.07 \\
\pm 0.01^{\mathrm{b}}\end{array}$ & $\begin{array}{c}3.66 \\
\pm 0.00^{\mathrm{a}}\end{array}$ & $\begin{array}{c}4.18 \\
\pm 0.01^{\mathrm{b}}\end{array}$ & $\begin{array}{c}1.60 \\
\pm 0.01^{\mathrm{b}}\end{array}$ & $\begin{array}{c}0.06 \\
\pm 0.00^{\mathrm{b}}\end{array}$ & $\begin{array}{c}2.94 \\
\pm 0.03^{\mathrm{a}}\end{array}$ \\
\hline $\begin{array}{l}\text { Pectinex } \\
\text { Ultra Pulp }\end{array}$ & $\begin{array}{c}6.85 \\
\pm 0.02^{\mathrm{a}}\end{array}$ & $\begin{array}{c}0.73 \\
\pm 0.05^{\mathrm{c}}\end{array}$ & $\begin{array}{c}0.07 \\
\pm 0.00^{\mathrm{b}}\end{array}$ & $\begin{array}{c}2.78 \\
\pm 0.00^{\mathrm{b}}\end{array}$ & $\begin{array}{c}8.68 \\
\pm 0.04^{\mathrm{a}}\end{array}$ & $\begin{array}{c}0.63 \\
\pm 0.05^{\mathrm{c}}\end{array}$ & $\begin{array}{c}0.26 \\
\pm 0.00^{\mathrm{a}}\end{array}$ & $\begin{array}{c}3.44 \\
\pm 0.00^{\mathrm{b}}\end{array}$ & $\begin{array}{c}7.56 \\
\pm 0.02^{\mathrm{a}}\end{array}$ & $\begin{array}{c}0.50 \\
\pm 0.05^{\mathrm{c}}\end{array}$ & $\begin{array}{c}0.54 \\
\pm 0.01^{\mathrm{a}}\end{array}$ & $\begin{array}{c}2.77 \\
\pm 0.03^{\mathrm{a}}\end{array}$ \\
\hline
\end{tabular}

${ }^{1) a-c}$ Means within the same column with different superscript letters are significant different by Duncan's multiple range test at $\mathrm{p}<0.05$ ( $\mathrm{n}=3$ ). 
hesperetin conversion by Viscozyme L and AMG 300L have previously been reported to be $\mathrm{pH} 3.0-5.0$ and $40-50^{\circ} \mathrm{C}$, which are similar to the results of this study (Ahn et al., 2005; Hyon et al., 2010)

Viscozyme L (from Aspergillus aculeatus) is a multienzyme complex with a wide range of carbohydrases including endo- $\beta-1,3(4)$-glucanase (as a key enzyme), arabanase, cellulase, hemicellulase and xylanase (Kim et al., 2015). This enzyme also has activity against the branched pectinlike substances found in cell walls. AMG $300 \mathrm{~L}$ is an exo-1,4-alpha-D-glucosidase (glucoamylase) obtained from Aspergillus niger, and Pectinex Ultra Pulp (from Aspergillus aculeatus and Aspergillus niger) has the enzyme activity of pectinase (Kim et al., 2015). Therefore, Viscozyme L appears to have the best ability to hydrolyze the sugar linked to the flavonoid glycosides hesperidin and naringin for conversion into hesperetin and narigenin, respectively.

The antioxidant activities of the standard hesperidin, hesperetin, naringin, and narigenin were evaluated with DPPH RSC. The DPPH RSC of aglycone was higher than that of glycoside, and the DPPH RSC of hesperetin was 1.6 times higher than that of hesperidin, and 6.6 times higher than that of narigenin $(p<0.05)$ (Fig. 1). The DPPH RSCs of the $24 \mathrm{~h}$ hydrolyzed hesperidin and naringin were compared by three commercial enzymes. The DPPH RSC of hydrolyzed hesperidin was the highest with Viscozyme L $(p<0.05)$, which may be due to its increased production of hesperetin with high antioxidant activity compared to the other two enzymatic hydrolysates (Table 1). For the hydrolyzed naringin, the DPPH RSCs of hydrolysates using Viscozyme L and AMG 300L were significantly higher than that of hydrolysate using Pectinex Ultra Pulp $(p<0.05)$. In addition, the DPPH RSC was higher in the hydrolysate of Viscozyme L than that of AMG 300L, but there was no significant difference $(p>0.05)$.

Given these results, the enzymatic reaction conditions for higher conversion of hesperidin into hesperetin was considered with Viscozyme L, reaction buffer $\mathrm{pH} 5.0$, and $24 \mathrm{~h}$. For higher conversion of naringin into narigenin, the reaction buffer was considered with $\mathrm{pH} 5.0$, and the enzyme was Viscozyme $\mathrm{L}$ for the $2 \mathrm{~h}$ reaction and AMG 300L and Pectinex Ultra Pulp for the $24 \mathrm{~h}$ reaction.

\section{Effect of enzyme reactions on flavonoid contents and DPPH RSCs in the hydrolyzed mature citrus}
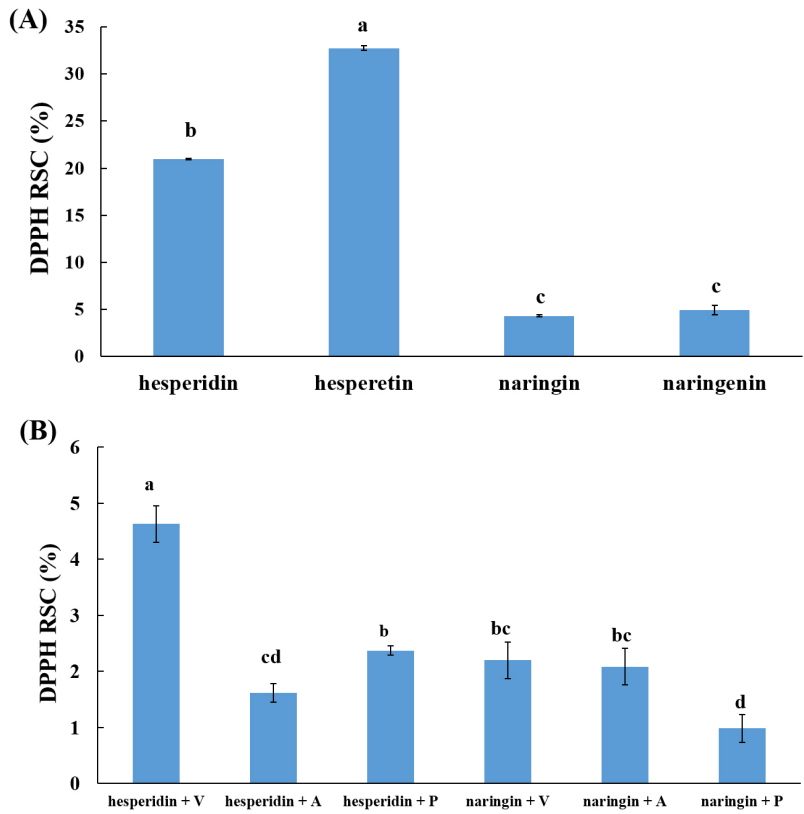

Fig. 1. The DPPH radical scavenging capacity (RSC, \%) of standard flavonoids (A), and the enzymatic hydrolyzed hesperidin and naringin (B) (V, Viscozyme L; A, AMG 300L; P, Pectinex Ultra Pulp).

Bars with different letters $\left({ }^{\mathrm{a}-\mathrm{d}}\right)$ are significantly different by Duncan's multiple range test at $\mathrm{p}<0.05$.

The flavonoid contents and DPPH RSCs of the hydrolyzed mature citrus were compared based on the type of enzyme and reaction time. After the enzyme reaction, a boiling process was conducted for the purpose of enzyme inactivation; thus, the effect of the boiling on the flavonoid contents and DPPH RSCs of the citrus was also determined (Table 3). Before the enzyme reaction, the mature citrus contained 205 times more hesperidin $(3,289 \mu \mathrm{g} / \mathrm{g})$ than naringin $(16 \mu \mathrm{g} / \mathrm{g})$, and a trace amount of hesperetin $(7 \mu \mathrm{g} / \mathrm{g})$ and narigenin $(1 \mu \mathrm{g} / \mathrm{g})$. After the enzymatic hydrolysis reaction, the content of hesperidin in the mature citrus decreased, while the contents of naringin, hesperetin, and narigenin tended to increase. The rates of decrease and increase were higher in the $24 \mathrm{~h}$ hydrolysate than the $2 \mathrm{~h}$ hydrolysate. Viscozyme L treatment produced more hesperetin and narigenin than AMG 300L and Pectinex Ultra Pulp $(p<0.05)$. The boiling process of the mature citrus resulted in a slight increase in the contents of hesperidin, naringin, and narigenin (Table 3), which may be the result of intracellular hesperidin extraction due to the hydrolysis of cell wall components by boiling. The change in flavonoid 
Table 3. The content of flavonoids and DPPH RSC in the hydrolyzed mature citrus by commercial enzymes

\begin{tabular}{|c|c|c|c|c|c|c|c|c|}
\hline \multirow{3}{*}{$\begin{array}{l}\text { Flavonoids } \\
\quad(\mu \mathrm{g} / \mathrm{g})\end{array}$} & \multirow{2}{*}{\multicolumn{2}{|c|}{$\begin{array}{c}\text { Mature citrus } \\
\text { (without enzyme) }\end{array}$}} & \multicolumn{6}{|c|}{ Enzymatically hydrolyzed mature citrus } \\
\hline & & & \multicolumn{3}{|c|}{$2 \mathrm{~h}$} & \multicolumn{3}{|c|}{$24 \mathrm{~h}$} \\
\hline & Before boiling & After boiling & Viscozyme L & AMG $300 \mathrm{~L}$ & $\begin{array}{l}\text { Pectinex } \\
\text { Ultra Pulp }\end{array}$ & Viscozyme L & AMG 300L & $\begin{array}{l}\text { Pectinex } \\
\text { Ultra Pulp }\end{array}$ \\
\hline Hesperidin & $3,289 \pm 13$ & $3,646 \pm 14^{* 1)}$ & $2,558 \pm 155^{\mathrm{b} 2)}$ & $3,419 \pm 57^{\mathrm{a}}$ & $3,161 \pm 53^{\mathrm{a}}$ & $106 \pm 6^{\mathrm{c}}$ & $3,558 \pm 220^{\mathrm{a}}$ & $2,442 \pm 26^{\mathrm{b}}$ \\
\hline Hesperetin & $7 \pm 0$ & $3 \pm 0^{*}$ & $595 \pm 139^{\mathrm{a}}$ & $16 \pm 1^{b}$ & $57 \pm 5^{\mathrm{b}}$ & $1,418 \pm 15^{\mathrm{a}}$ & $63 \pm 2^{\mathrm{c}}$ & $315 \pm 6^{\mathrm{b}}$ \\
\hline Naringin & $16 \pm 0$ & $18 \pm 2^{\mathrm{NS} 3)}$ & $10 \pm 1^{b}$ & $33 \pm 1^{\mathrm{a}}$ & $34 \pm 2^{\mathrm{a}}$ & $38 \pm 3^{\mathrm{a}}$ & $32 \pm 1^{\mathrm{b}}$ & $30 \pm 1^{\mathrm{b}}$ \\
\hline Narigenin & $1 \pm 0$ & $3 \pm 0^{*}$ & $262 \pm 21^{a}$ & $20 \pm 4^{c}$ & $80 \pm 7^{b}$ & $314 \pm 10^{\mathrm{a}}$ & $105 \pm 2^{\mathrm{c}}$ & $210 \pm 5^{\mathrm{b}}$ \\
\hline DPPH RSC (\%) & $40.56 \pm 0.24^{*}$ & $31.74 \pm 0.00$ & $\mathrm{NA}^{4)}$ & NA & NA & $30.24 \pm 0.80^{\mathrm{a}}$ & $23.90 \pm 0.80^{\mathrm{b}}$ & $30.24 \pm 0.16^{\mathrm{a}}$ \\
\hline
\end{tabular}

contents was much higher in enzymatic hydrolysis than in the boiling process.

To convert citrus flavonoid glycosides into aglycone, cell-wall polysaccharides (e.g., cellulose, hemicellulose, pectin, and $\beta$-glucan) should be hydrolyzed before the glycosides are released outside of the cells, and followed by hydrolysis of the glycosides. The increases in hesperetin and narigenin contents in Table 3 appears to be the result of the degradation of cell wall polysaccharides as well as hydrolysis of the released flavonoid glycosides by the commercial carbohydrases. Of these carbohydrases, Viscozyme $\mathrm{L}$ resulted in the highest production rate of hesperetin and naringenin. Viscozyme $\mathrm{L}$ is a multi-enzyme complex having the activity of $\beta$-glucanase, arabanase, cellulase, hemicellulase, and xylanase. $\beta$-glucanase acts on the degradation of cellulose by randomly cleaving glucosidic bonds within $\beta$-1,4-glucan, and releasing glucose and cello-oligosaccharides (Meinke et al., 1995). Viscozyme L appears to be more suitable for extraction of citrus flavonoids and conversion into hesperetin and narigenin than AMG 300L and Pectinex Ultra Pulp, which have activities of glucoamylase and pectinase, respectively.

The DPPH RSC of the mature citrus was higher in the order of before boiling $(40.56 \%)>$ after boiling $(31.74 \%)$ $>$ enzyme treatment at $24 \mathrm{~h}(23.9-30.24 \%)$ with a significant difference $(\mathrm{p}<0.05)$ (Table 3$)$. This result suggests that the DPPH RSC decreased because the antioxidants (e.g., phenols, flavonoids, carotenoids and vitamin C) present in mature citrus were destroyed or lost during enzymatic hydrolysis and the boiling process. The DPPH RSC of the AMG 300L hydrolysate containing the lowest content of hesperetin and naringenin was the lowest $(23.9 \%)(\mathrm{p}<0.05)$, and there was no significant difference in DPPH RSCs between Viscozyme L and Pectinex Ultra Pulp hydrolysates $(\mathrm{p}>0.05)$.

\section{Comparison of flavonoids, TPCs, and DPPH RSCs of the hydrolyzed mature and immature citrus}

The citrus peel contains more effective bioactive compounds such as dietary fibers, carotenoids, and flavonoids than the citrus pulp. The peel contained higher amount of vitamin $C$, carotenoids, pectin and hesperidin than the pulp (Yang et al., 2008). Eun et al. (1996) also reported higher contents of hesperidin and naringin (5.9 and 3.7 times, respectively), higher total dietary fiber content (2.6 times), and higher contents of cellulose and hemicellulose (13.7 and 2.1 times, respectively) in the peel than in the pulp. The amounts of citrus bioactive compounds depend on their maturity of the fruits. The juice of immature citrus contains a higher organic acid and lower free sugar contents, and the hesperidin and naringin contents decrease as the citrus matures (Song et al., 1998). Flavonoids and TPCs of the citrus fruit increase with maturation, and decrease with ripening (Kim et al., 2009). The DPPH radical and hydrogen peroxide scavenging activity levels of immature citrus with peel (harvested in September) were lower than those of 
mature citrus (harvested in November) (Lee et al., 2015).

Naringin, a substance that results in bitter taste of citrus, is combined with the pectin substances of fruit, remained insoluble, and eluted into fruit juice during processing ( $\mathrm{Li}$ et al., 2014). Hesperidin, a tasteless substance, binds to the citrus pulp, and remains in an insoluble form (Putnik et al., 2017). However, during the canning process with heat treatment, hesperidin is deposited from the citrus, and causes the formation of a white crystal, leading to white patches on the citrus pieces as well as turbidity in the syrup of the canned fruit, affecting product quality (Terada et al., 1995). Compared to mature citrus, immature citrus is less frequently used in processed products because it has more peel parts and higher content of hesperidin, naringin, and dietary fiber contents. However, if these substances are hydrolyzed and converted to their aglycones through enzyme treatment, the bioactive effects and the quality of processed products can be improved.

In this study, mature and immature citrus with both pulp and peel were hydrolyzed using Viscozyme L and boiled for enzyme inactivation after hydrolysis. Control of citrus at 0 $\mathrm{h}$ was also boiled for comparison with the hydrolyzed citrus. The hesperidin content of immature citrus was 2.41 times higher than that of mature citrus $(\mathrm{p}<0.05)$, and the DPPH RSCs and TPCs were higher in immature than in mature citrus $(\mathrm{p}<0.05)$ (Table 4$)$. The $24 \mathrm{~h}$ hydrolyzed immature citrus contained 1.63 and 2.10 times higher hesperetin and narigenin contents than the mature citrus, respectively (Fig. 2 and 3). After $24 \mathrm{~h}$ of hydrolysis, $106 \mu \mathrm{g} / \mathrm{g}$ hesperidin remained in the mature hydrolysate, while $2,198 \mu \mathrm{g} / \mathrm{g}$ remained in the immature hydrolysate, therefore, more hesperetin is produced as the enzyme amount or reaction time increases.

During the hydrolysis by Viscozyme L, cell-wall polysaccharides were degraded, and the intracellular hesperidin, naringin, and phenolic compounds were extracted and hydrolyzed, resulting in the conversion into hesperetin and narigenin as well as increased TPCs. The TPCs increased continuously during the hydrolysis, and the TPC of immature hydrolysate was significantly higher than that of the mature hydrolysate at both the $2 \mathrm{~h}$ and $24 \mathrm{~h}$ reaction times $(\mathrm{p}<0.05)$. The DPPH RSC increased in the $2 \mathrm{~h}$ reaction but decreased in the $24 \mathrm{~h}$ reaction. In addition, the DPPH RSC was significantly higher in immature citrus hydrolysate than in the mature citrus hydrolysate at $2 \mathrm{~h}$ $(\mathrm{p}<0.05)$, but there was no significant difference at $24 \mathrm{~h}$ $(\mathrm{p}>0.05)$.

Thus, by using of immature citrus rather than mature citrus, enzymatic hydrolysate with much higher contents of hesperetin, narignenin, and TPCs can be obtained. The enzymatic hydrolysis of immature citrus can be utilized to improve a quality of various citrus beverages, and the hydrolyzed citrus may serve as a food additive with high added value in the citrus food processing industry.

Table 4. The content of flavonoids and total phenolics, and DPPH RSCs of the hydrolyzed mature and immature citrus by Viscozyme L

\begin{tabular}{|c|c|c|c|c|c|c|}
\hline & \multicolumn{6}{|c|}{ Hydrolyzed citrus by Viscozyme L } \\
\hline & \multicolumn{2}{|c|}{$0 \mathrm{~h}^{2)}$} & \multicolumn{2}{|c|}{$2 \mathrm{~h}$} & \multicolumn{2}{|c|}{$24 \mathrm{~h}$} \\
\hline & Mature & Immature & Mature & Immature & Mature & Immature \\
\hline \multicolumn{7}{|l|}{ Flavonoids $(\mu \mathrm{g} / \mathrm{g})$} \\
\hline Hesperidin & $3,646 \pm 14$ & $8,609 \pm 168^{* 3)}$ & $2,558 \pm 155$ & $6,827 \pm 354^{*}$ & $106 \pm 6$ & $2,198 \pm 60^{*}$ \\
\hline Hesperetin & $3 \pm 0$ & $0 \pm 0^{*}$ & $595 \pm 139$ & $649 \pm 20^{*}$ & $1,418 \pm 15$ & $2,318 \pm 16^{*}$ \\
\hline Naringin & $18 \pm 2$ & $7 \pm 0^{*}$ & $10 \pm 1$ & $6 \pm 1^{*}$ & $38 \pm 3$ & $32 \pm 2^{\mathrm{NS}}$ \\
\hline Narigenin & $3 \pm 0$ & $2 \pm 1^{\mathrm{NS} 4)}$ & $262 \pm 21$ & $420 \pm 7^{*}$ & $314 \pm 10$ & $660 \pm 6^{*}$ \\
\hline $\mathrm{TPC}\left(\mathrm{GAE}^{1)} \mathrm{mg} / \mathrm{g}\right)$ & $2.25 \pm 0.06$ & $2.35 \pm 0.14^{*}$ & $2.35 \pm 0.10$ & $3.25 \pm 0.01^{*}$ & $2.25 \pm 0.06$ & $3.80 \pm 0.00^{*}$ \\
\hline DPPH RSC(\%) & $31.74 \pm 0.00$ & $35.54 \pm 0.45^{*}$ & $36.46 \pm 0.32$ & $38.83 \pm 0.61^{*}$ & $32.17 \pm 1.12$ & $30.45 \pm 1.41^{\mathrm{NS}}$ \\
\hline
\end{tabular}

${ }^{1)} \mathrm{GAE}$, gallic acid equivalent.

${ }^{2}$ No enzyme treated.

3)* Indicate a significant difference between the hydrolyzed mature and immature citrus by Student's t-test at $\mathrm{p}<0.05(\mathrm{n}=3)$.

${ }^{4} \mathrm{NS}$, not significant. 

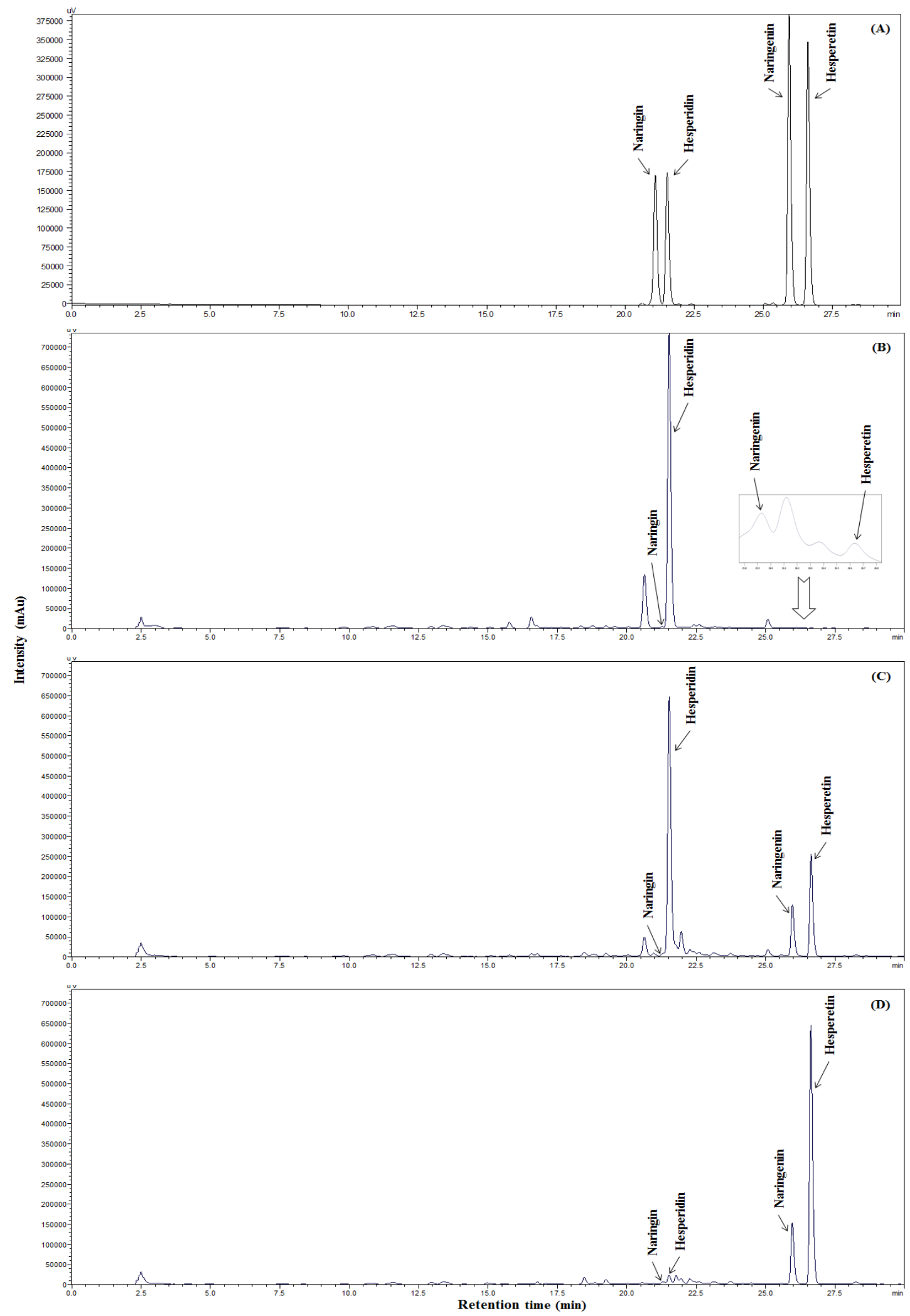

Fig. 2. The HPLC chromatograms of standards hesperidin and hesperetin (A), mature citrus (B), hydrolyzed mature citrus by Viscozyme $L$ for $2 h(C)$ and $24 h(D)$. 

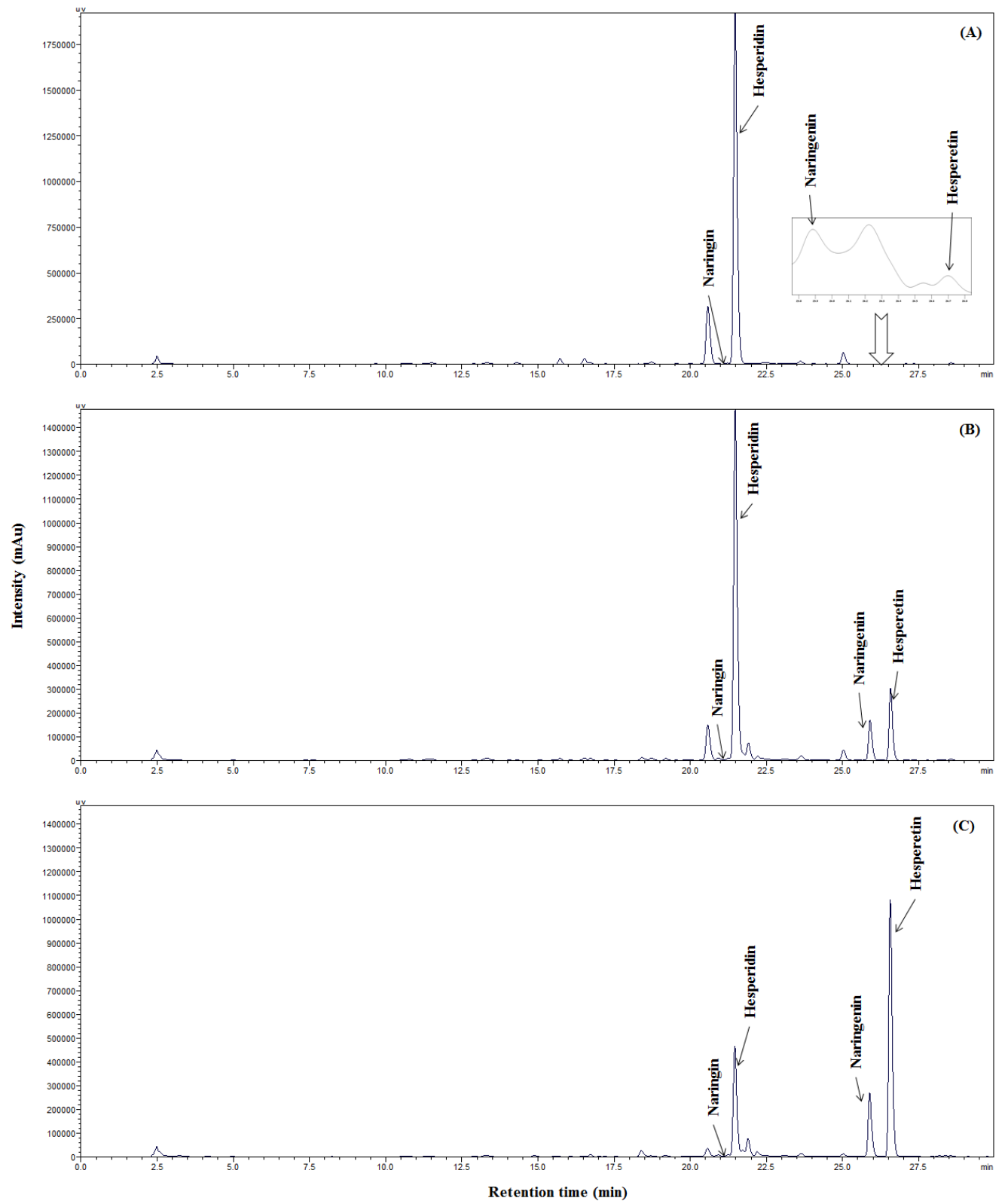

Fig. 3. The HPLC chromatograms of immature citrus (A), hydrolyzed mature citrus by Viscozyme L for 2 h (B) and 24 h (C).

MIC of the hydrolyzed immature citrus against $S$. aureus and $E$. coli

The antimicrobial effect of the hydrolyzed immature citrus against $S$. aureus and $E$. coli was concentration dependent (Table 5). The MICs of the immature citrus extracts against $S$. aureus and E. coli were $9.38 \mathrm{mg} / \mathrm{mL}$ and $37.5 \mathrm{mg} / \mathrm{mL}$, respectively, but, after hydrolysis, decreased to $1.17-4.69 \mathrm{mg} / \mathrm{mL}$ (for $S$. aureus) and $9.38 \mathrm{mg} / \mathrm{mL}$ (for $E$. coli), respectively, indicating an increased antimicrobial effect (Table 5). For $S$. aureus, the MIC of the $24 \mathrm{~h}$ hydrolysate $(1.17 \mathrm{mg} / \mathrm{mL})$ was lower than the $2 \mathrm{~h}$ hydrolysate $(4.69 \mathrm{mg} / \mathrm{mL})$, showing a growth inhibitory effect with a longer enzymatic hydrolysis reaction time. However, for E. coli, the MIC of the $2 \mathrm{~h}$ hydrolysate (9.38 $\mathrm{mg} / \mathrm{mL}$ ) was maintained in the $24 \mathrm{~h}$ hydrolysate, revealing that the antimicrobial effect of the immature citrus hydrolysate was more potent against $S$. aureus than $E$. coli. According to studies by Yashaswini and Arvind (2018) 
Table 5. The minimum inhibitory concentration (MIC) of the hydrolyzed immature citrus by Viscozyme L

\begin{tabular}{cccc}
\hline \multirow{2}{*}{ Microorganisms } & \multicolumn{3}{c}{ MIC $(\mathrm{mg} / \mathrm{mL})$} \\
\cline { 2 - 4 } & $0 \mathrm{~h}^{1)}$ & $2 \mathrm{~h}$ & $24 \mathrm{~h}$ \\
\hline Staphylococcus aureus & $9.38 \pm 0.0$ & $4.69 \pm 0.0$ & $1.17 \pm 0.0$ \\
Escherichia coli & $37.50 \pm 0.0$ & $9.38 \pm 0.0$ & $9.38 \pm 0.0$ \\
\hline
\end{tabular}

${ }^{1)}$ No enzyme treated.

and Ahn et al. (2007), the MIC of orange peel extract against $S$. aureus $(781.25 \mu \mathrm{g} / \mathrm{mL})$ was lower than that of $E$. coli $(3,125 \mu \mathrm{g} / \mathrm{mL})$, similarly to the results of this study. Xie et al. (2017) reported that the antibacterial activities of hesperetin and narigenin against $E$. coli and $S$. aureus were higher than those of their glycosides, hesperidin and naringin. Generally, citrus fruit extract showed a much stronger antimicrobial effect against gram-positive bacteria (S. aureus) than gram-negative bacteria (E. coli) (Yi et al., 2008), which may be due to the tight penetration barrier that results in relative impermeability of the outer membrane that surrounding gram-negative bacteria (Ikaigai et al., 1993).

From this study, the hydrolysate obtained through the enzymatic treatment of immature unpeeled citrus shows the potential to be used in food processing as a natural food material with antioxidant and antimicrobial activities.

\section{Acknowledgement}

This research was supported by the Daegu University Research Grant, 2016.

\section{Conflict of interests}

The authors declare no potential conflict of interest.

\section{ORCID}

Kwang-Seup Shin https://orcid.org/0000-0002-5098-1121

Jeung-Hee Lee https://orcid.org/0000-0002-4224-771X

\section{References}

Ahn MS, Kim HJ, Seo MS. A study on the antioxidative and antimicrobial activities of the Citrus unshju peel extracts. Korean J Food Culture, 22, 454-461 (2007)
Ahn SC, Kim MS, Lee SY, Kang JH, Kim BH, Oh WK, Kim BY, Ahn JS. Increase of bioactive flavonoid aglycone extractable from Korean citrus peel by carbohydratehydrolysing enzymes. Korean J Microbial Biotechnol, 33, 288-294 (2005)

Arts ICW, Sesink ALA, Faassen-Peters M, Hollman PCH. The type of sugar moiety is a major determinant of the small intestinal uptake and subsequent biliary excretion of dietary quercetin glycosides. Br J Nutr, 91, 841-847 (2004)

Eun JB, Jung YM, Woo GJ. Identification and determination of dietary fibers and flavonoids in pulp and peel of Korean Tangerine (Citrus aurantium var.). Korean J Food Sci Technol, 28, 371-377 (1996)

Garg A, Garg S, Zaneveld LJD, Singla AK. Chemistry and pharmacology of the citrus bioflavonoid hesperidin. Phytother Res, 15, 655-669 (2001)

Hollman PC, Bijsman MN, van Gameren Y, Cnossen EP, de Vries JH, Katan MB. The sugar moiety is a major determinant of the absorption of dietary flavonoid glycosides in man. Free Radic Res, 31, 569-573 (1999)

Hyon JS, Kang SM, Senevirathne M, Koh WJ, Yang TS, Oh MC, Oh CK, Jeon YJ, Kim SH. Antioxidative activities and enzymatic digests from dried Citrus unshiu and Citrus grandis peels. Korean J. Food Cookery Sci, 26, 18-25 (2010)

Hyun JM, Park KJ, Kim SS, Park SM, Lee YJ, An HJ. Antioxidant and anti-inflammatory effects of solvent fractions from the peel of the native Jeju citrus 'Hongkyool' and 'Pyunkyool'. J Life Sci, 25, 1132-1138 (2015)

Ikaigai H, Nakae T, Hara Y, Shimamura T. Bactericidal catechins damage the lipid bilayer. Biochim Biophys Acta Biomembr, 1147, 132-136 (1993)

Izumi T, Piskula MK, Osawa S, Obata A, Tobe K, Saito M, Kataoka S, Kubota Y, Kikuchi M. Soy isoflavone aglycones 
are absorbed faster and in higher amounts than their glucosides in humans. J Nutr, 130, 1695-1699 (2000)

Kawaii S, Ikuina T, Hikima T, Tokiwano T, Yoshizawa Y. Relationship between structure and antiproliferative activity of polymethoxyflavones towards HL60 cells. Anticancer Res, 32, 5239-5244 (2012)

Kim AR, Kim DH, Jeong GT. Optimum reaction condition of enzymatic hydrolysis for production of reducing sugar from Enteromorpha intestinalis. Korean Soc Biotechnol Bioeng J, 30, 53-57 (2015)

Kim YD, Ko WJ, Koh KS, Jeon YJ, Kim SH. Composition of flavonoids and antioxidative activity from juice of Jeju native citrus fruits during maturation. Korean $\mathrm{J}$ Nutr, 42, 278-290 (2009)

Lee JE, Kim JH, Kim MY. Changes in phenolic composition, antioxidant and antidiabetic properties of Jeju Citrus sudachi as influenced by maturity. J Life Sci, 25, 13111318 (2015)

Lee SH, Park HJ, Back OH, Chun HK, Rhie SG, Lee GS. Comparison of the nutritional composition of 3 kinds of citrus produced on Jeju Island Korea. Korean J Community Living Science, 16, 15-20 (2005)

Li SJ, Wang Z, Ding F, Sun D, Ma ZC, Cheng YJ, Xu J. Content changes of bitter compounds in 'Guoqing No.1' Satsuma mandarin (Citrus unshiu Marc.) during fruit development of consecutive 3 seasons. Food Chem, 145, 963-969 (2014)

Meinke A, Damude HG, Tomme P, Kwan E, Kilburn DG, Miller RC, Warren RAJ, Gilkes NR. Enhancement of the endo- $\beta$-1,4-glucanase activity of an exocellobiohyrolase by deletion of surface loop. J Biol Chem, 270, 43834386 (1995)

Nielsen ILF, Chee WSS, Poulsen L, Offord-Cavin E, Rasmussen SE, Frederiksen H, Enslen M, Barron D, Horcajada MN, Williamson G. Bioavailability is improved by enzymatic modification of the citrus flavonoid hesperidin in humans: A randomized, double-blind, crossover trial. J Nutr, 136, 404-408 (2006)

Putnik P, Barba FJ, Lorenzo JM, Gabric D, Shpigelman A, Cravotto G, Kovacevic DB. An intergrated approach to mandarin processing: Food safety and nutritional quality, consumer presence, and nutrient bioaccessibility. Compr Rev Food Sci Food Saf, 16, 1345-1358 (2017)

Ribeiro DS, Henrique SMB, Oliveira LS, Macedo GA, Fleuri LF. Enzymes in juice processing: A review. Int $\mathrm{J}$ Food Sci Tecnol, 45,635-641 (2010)

Song EY, Choi YH, Kang KH, Koh JS. Free sugar, organic acid, hesperidin, naringin and inorganic elements changes of Cheju citrus fruits according to harvest date. Korean J Food Sci Technol, 30, 306-312 (1998)

Song YW, Moon KS, Cho SK. Antioxidant activity and nutrient content of ethanol and hot-water extracts of Citrus unshiu pomace. J Korean Soc Food Sci Nutr, 42, 1345-1350 (2013)

Terada Y, Kometani T, Nishimura T, Takii H, Okada S. Prevention of hesperidin crystal formation in canned mandarin orange syrup and clarified orange juice by hesperidin glycosides. Food Sci Technol Int Tokyo, 1, 29-33 (1995)

Tripoli E, Guardia ML, Giammanco S, Majo DD, Giammanco M. Citrus flavonoids: Molecular structure, biological activity and nutritional properties: A review. Food Chem, 104, 466-479 (2007)

Xie Y, Chen J, Xiao A, Liu L. Antibacterial activity of polyphenols: Structure-activity relationship and influence of hyperglycemic condition. Molecules, 22, 1913 (2017)

Yashaswini P, Arvind. Antimicrobial properties of orange (Citrus reticulata var. Kinnow) peel extracts against pathogenic bacteria. Int J Curr Microbiol App Sci, 7, 737-746 (2018)

Yang YT, Kim MS, Hyun KH, Kim YC, Koh JS. Chemical constituents and flavonoids in citrus pressed cake. Korean J Food Preserv, 15, 94-98 (2008)

Yao X, Zhu X, Pan S, Fang Y, Jiang F, Phillips GO, Xu X. Antimicrobial activity of nobiletin and tangeretin against Pseudomonas. Food Chem, 132, 1883-1890 (2012)

Yi Z, Yu Y, Liang Y, Zeng B. In vitro antioxidant and antimicrobial activities of the extract of Pericarpium citri Reticulatae of a new citrus cultivar and its main flavonoids. LWT-Food Sci Technol, 41, 597-603 (2008) 